\title{
Menakar Hermeneutika Fusion of Horizons H.G. Gadamer dalam Pengembangan Tafsir Maqasid Alquran
}

\author{
Oleh: Rahmatullah \\ Email: rahmatalbarawi6@gmail.com \\ Young Interfaith Peasmakar Community, Indonesia
}

\begin{abstract}
Abstrak
Gadamer merupakan salah satu tokoh hermeneutika yang cukup populer dengan gagasannya fusion of horizons. Tawaran tersebut menjadi salah satu tawaran alternatif untuk memahami teks secara proporsional dan dapat diaplikasikan untuk memahami setiap teks termasuk teks kitab suci. Tulisan sederhana ini mencoba memahami gagasan fusion of horizons dan hubungannya dengan penafsiran Alquran. Melalui pembacaan hermeneutika Gadamer, sikap terbaik untuk mendapatkan pemahaman yang komprehensif adalah pertama, kemauan terbuka untuk menerima gagasan dan wawasan baru. Hal ini penting untuk memperluas cakrawala seseorang sehingga ia dapat menjangkau hal-hal yang lebih luas lagi. Kedua, menghasilkan pemahaman baru atau memproduksi sesuatu yang baru. Meski demikian, perlu digarisbawahi bahwa kebaruan gagasan tidak dapat diperoleh tanpa memahami sejarah masa lampau. Ketiga, pemahaman yang efektif bukanlah pemahaman yang berdiri sendiri, justru pemahaman yang valid adalah pemahaman yang bersumber dan ditopang dari horizon-horizon yang beragam. Semakin luas horizon, semakin luas pula pemahamannya. Keempat, semangat fusion of horizon dapat dikembangkan dalam konteks memahami
\end{abstract}


Alquran dengan menggunakan tafsir maqasid Alquran, sehingga nilai-nilai Alquran dapat selaras dengan waktu dan tempat, shalih li kulli zaman wa makan.

Kata kunci: Gadamer, fusion of horizons, maqasid Alquran.

\section{A. Pendahuluan}

Setiap manusia tidak terlepas dari proses memahami yang menghasilkan pengetahuan. Pengetahuan manusia selalu merupakan pengetahuan akan sesuatu atau dalam bahasa Husserl disebut bahwa pengetahuan adalah intensional. ${ }^{1}$ Maksudnya bahwa pengetahuan seseorang selalu terarah kepada objek di luar dirinya. Sedangkan gambaran seseorang terhadap objek luar tersebut tergantung pada cakrawala pemahamannya (horizons).

Sedangkan cakrawala pemahaman seseorang sangat bergantung pada prasangka (prejudice) yang dimilikinya. Disinilah letak pentingnya memahami kajian hermeneutika untuk mengetahui bagaimana pemahaman tersebut dibangun. Sebagaimana yang ditegaskan oleh Gadamer berikut:

First of all, as a hermeneutical task, understanding includes a reflective dimension from the very beginning. Understanding is not a mere reproduction of knowledge, that is, it is not a mere act of repeating the same thing. Rather, understanding is aware of the fact that it is indeed an act of repeating. ${ }^{2}$

Berdasarkan ungkapan Gadamer tersebut, dapat diketahui bahwa memahami sesuatu harus diawali dengan dimensi reflektif (reflective dimension). Dimensi reflektif ini mencakup dialektika antara prapemahaman seseorang dikaitkan dengan realitas yang saat ini dihadapi, sehingga hasil pemahaman tersebut juga merupakan hal baru, bukan pengulangan dari pemahaman sebelumnya. Sebagai contoh, dalam

1 F. Budi Hardiman, Melawan Positivisme dan Modernitas: Diskursus Filosofis tentang Metode Ilmiah dan Problem Modernitas, (Yogyakarta: Kanisius, 2003), hlm. 45.

2 Gadamer, Hans-Georg, Philosophical Hermeneutics, Terj. David E. Linge, (London: University of California Press, 2008), hlm. 45. 
memahami Alquran, seorang dokter akan berbeda pemahamannya dengan seorang guru. Sebab, sejak awal starting point-nya sudah berbeda dipengaruhi oleh horizon sang pembaca kitab suci. Lantas bagaimana agar pemahaman tersebut valid?. Gadamer menawarkan peleburan horizon (fusion of horizon) sebagai cara untuk memahami suatu teks.

Inilah tugas hermeneutik menurut Gadamer yaitu proses memahami wawasan (horizon). Hal Ini juga menjadi salah satu kekhasan hermeneutik-nya. Sebab, ia mengkritik para pengkaji hermeneutika terdahulu seperti Schleiermacher dan Dilthey. Bahkan, menurut Palmer, salah satu momen yang sangat menentukan dalam perkembangan teori hermeneutika modern adalah kehadiran buku Wahrheit und Methode karya Gadamer. ${ }^{3}$

Sedangkan menurut Sahiron Syamsuddin, hermeneutika yang ditawarkan oleh Gadamer berada di posisi tengah, yaitu aliran obyektivis-cum-subyektivis. ${ }^{4}$ Kebaruan gagasan yang ditawarkan oleh Gadamer sekaligus corak yang membuatnya berada di aliran tengah adalah teori seputar fusion of horizon. Bagaimana cara kerja dari teori tersebut dan korelasinya dalam ulum Alquran, khususnya dalam menggagas tafsir maqasid Alquran?. Tulisan sederhana berikut akan membahasnya.

\section{B. Perjalanan Intelektual Gadamer}

Gadamer merupakan seorang filsuf dan pemikir yang hidup sepanjang abad ke-20. Ia lahir di Marburg tanggal 11 Februari 1990 dari kalangan keluarga menengah dan memiliki karir akademik yang tinggi. Ayahnya seorang ahli kimia dan memuja ilmu-ilmu alam dan merendahkan kajian humaniora. ${ }^{5}$ Namun, ternyata pepatah 'buah jatuh

3 Richard E. Palmer, Hermeneutika Teori Baru Mengenai Interpretasi, Terj. Musnur Hery dan Damanhuri Muhammed, (Yogyakarta: Pustaka Pelajar, 2005), hlm. 190.

4 Sahiron Syamsuddin, Hermeneutika dan Pengembangan Ulumul Qur 'an: Edisi Revisi dan Perluasan, (Yogyakarta: Nawasea Press, 2017), hlm. 50.

5 F. Budi Hardiman, Seni Memahami: Hermeneutik dari Schleiermacher sampai Derrida, (Yogyakarta: Kanisius, 2015), hlm. 156-157. 
tidak jauh dari pohonnya' tidak berlaku dalam kehidupan intelektual Gadamer. Ia memutuskan untuk terjun dalam dunia filsafat.

Kecintaan Gadamer pada dunia filsafat bermula dari pembacaannya terhadap karya agung Immanuel Kant, Kritik der Reinen Vernunft (Critique of Pure Reason) di perpustakaan pribadi ayahnya. ${ }^{6}$ Dalam pembacaannya terhadap Immanuel Kant sebenarnya sudah terjadi proses fusion of horizon, manakala Gadamer dengan horizon ilmu alam yang banyak diberikan oleh ayahnya dan membaca karya Kant yang penuh dengan kajian filsafat moral. Pada akhirnya, aplikasi dari pemahaman Gadamer terhadap filsafat Kant membawanya menjadi filsuf ternama saat ini.

Selanjutnya Gadamer pun banyak menimba ilmu kepada beberapa filsuf terkenal seperti Heidegger, Nikolai Hartman, dan Rudolf Bultmann. ${ }^{7}$ Khususnya perjumpaan Gadamer dengan Heidegger banyak mempengaruhi pemikiran filsafatnya. Melalui Heidegger juga, ia belajar tentang pra-struktur pemahaman yang terikat dengan dimensi ontologis manusia, disebut dasein. Menurut Gadamer, proyeksi (entwurf) sudah selalu menyertai setiap kegiatan interpretasi, sehingga jika seorang penafsir membersihkan dirinya dari proyeksinya, dia berada dalam sebentuk proyeksi lain. ${ }^{8}$

Selama perjalanan karir intelektualnya, Gadamer melahirkan banyak karya sebagai simbol produktivitas keilmuannya, di antaranya:

- Hermeneutik I, Wahrheit und Methode. Grundzuge einer philosophischen Hermeneutik, 1986.

- Hermeneutik II, Wahrheit und Methode. Erganzungen. Register, 1986.

- Neuere Philosophie I. Hegel - Husserl - Heidegger, 1987.

- Neuere Philosophie II. Probleme - Gestalten, 1987.

6 Martinho G. Da Silva Gusmao, Hans-Georg Gadamer: Penggagas Filsafat Hermeneutik Modern yang Mengagungkan Tradisi, (Yogyakarta: Kanisius, 2012), hlm. 3.

7 E. Sumaryono, Hermeneutik Sebuah Metode Filsafat: Edisi Revisi, (Yogyakarta: Kanisius, 1999), hlm. 67

8 F. Budi Hardiman, Seni Memahami..., hlm. 168. 
- Griechische Philosophie I, 1985.

- Griechische Philosophie II, 1985.

- Griechische Philosophie III, Plato im Dialog, 1991.

- Asthetik und Poetik I. Kunst als Aussage, 1993.

- $\quad$ Asthetik und Poetik II. Hermeneutik im Vollzug, 19993.

- Hermeneutik im Ruckblick, $1995 .{ }^{9}$

Hermeneutika Gadamer selanjutnya menjadi kritik atas pemikiran hermeneutika yang dikembangkan oleh Schleiermacher dan Dilthey. Sebagaimana yang dikemukakan oleh F. Budi Hardiman, salah satu pokok gagasan Gadamer adalah meninggalkan romantisme Schleiermacher dan historisme Dilthey. Ia menegaskan:

Gadamer berpendapat bahwa pembaca tidak dapat kembali ke masa silam untuk menemukan kembali makna asli yang dimaksud oleh penulis teks. Kesadaran kita tidak berada di luar sejarah, melainkan bergerak di dalam sejarah, sehingga pemahaman kita juga dibentuk oleh sejarah. dengan kata lain, pemahaman kita berada di dalam sebuah horizon tertentu. ${ }^{10}$

Berdasarkan uraian tersebut, satu kata kunci yang perlu digarisbawahi adalah pemahaman kita berada di dalam sebuah horizon tertentu. Dengan demikian, penting untuk memahami keragaman horizon tersebut yang pada akhirnya melahirkan pemahaman yang lebih komprehensif.

\section{Hermeneutika Filosofis: Fusion of Horizons}

Sebagaimana pembahasan sebelumnya, hermeneutika Gadamer banyak terinspirasi dari pemikiran filsafat Heidegger, sehingga hermeneutika Gadamer pun cenderung hermeneutika filosofis. ${ }^{11}$ Maksudnya adalah bahwa proses pemahaman bukan dibangun atas dasar langkah metodologis sebagaimana yang digagas oleh

9 Martinho G. Da Silva Gusmao, Hans-Georg Gadamer..., hlm. 34.

10 F. Budi Hardiman, Seni Memahami..., hlm. 167.

11 Lebih lanjut lihat Sahiron Syamsuddin, Hermeneutika..., hlm. 17; Richard E. Palmer, Hermeneutika Teori Baru..., hlm. 192. 
Schleiermacher. Bahkan ia menegaskan bahwa metode bukanlah cara menuju kebenaran. Tetapi, pemahaman sebagai sebuah proses ontologis dalam diri manusia. ${ }^{12}$ Pemahaman bukan sesuatu yang datang dari luar, tetapi menjadi keberadaan dan eksistensi dari diri manusia itu sendiri. Dalam bahasa yang lebih sederhana, hermeneutika filosofis tidak berbicara seputar metode penafsiran, melainkan hal-hal yang terkait dengan condition of possibility (kondisi-kondisi kemungkinan) yang dengannya seseorang dapat memahami sebuah teks. ${ }^{13}$

Salah satu condition of possibility yang dijelaskan oleh Gadamer adalah fusion of horizon. Ia menjelaskan:

Every finite present has its limitations. We define the concept of "situation" by saying that it represents a standpoint that limits the possibility of vision. Hence essential to the concept of situation is the concept of horizon. The horizon is the range of vision that includes everything that can be seen from a particular vantage point. Applying this to the thinking mind, we speak of narrowness of horizon, of the possible expansion of horizon, of the opening up of new horizons, and so forth...A person who has no horizon does not see far enough and hence over-values what is nearest to him. ${ }^{14}$

Memahami penjelasan Gadamer tersebut, dapat diketahui bahwa horizon adalah jangkauan penglihatan yang mencakup segala hal yang dapat dilihat dari sudut pandang tertentu. Sehingga keluasan horizon menentukan pemahaman seseorang karena ia tidak akan bisa berpikir melampaui horizon yang dimilikinya.

Istilah horizon sebenarnya bukanlah istilah yang asli dari Gadamer, melainkan meminjam istilah dari fenomenologi Husserl. Sedangkan yang dimaksud dengan fusion of horizon adalah bahwa memahami merupakan aktivitas peleburan antara horizon masa lalu dari teks dan horizon masa kini dari pembaca. ${ }^{15}$ Lebih lanjut, ada dua ciri horizon, pertama, sebuah horizon tidak terisolasi, melainkan terbuka. Kedua,

12 Richard E. Palmer, Hermeneutika Teori Baru..., hlm. 191.

13 Sahiron Syamsuddin, Hermeneutika..., hlm. 17.

14 Hans-Georg Gadamer, Truth and Method, Terj. Joel Weinsheimer dan Donald G. Marshall, (London: Continuum, 2004), hlm. 301.

15 F. Budi Hardiman, Seni Memahami..., hlm. 163. 
horizon tidak statis, melainkan dinamis, terus bergerak. Gadamer menegaskan sebagai berikut:

Hence the horizon of the present cannot be formed without the past. There is no more an isolated horizon of the present in itself than there are historical horizons which have to be acquired. Rather, understanding is always the fusion of these horizons supposedly existing by themselves. ${ }^{16}$

Dengan kata lain, Gadamer ingin menegaskan bahwa tidak ada pemahaman yang 'steril' atau obyektif seutuhnya. Hal ini sekaligus mengkritik hermeneutika pendahulunya yang menganggap bahwa proses memahami itu berada di luar horizon, melainkan justru bergerak di dalam horizon. Karenanya tugas interpretasi tidak lain adalah memproyeksikan sebuah horizon historis yang berbeda dari horizon kekinian. ${ }^{17}$ Sehingga interpretasi bukanlah rekonstruksi atau representasi melainkan sebuah upaya produksi untuk menghasilkan makna baru.

Gadamer menunjukkan sikap berseberangan dengan kesadaran metodologis yang dipertahankan oleh ilmu-ilmu kemanusiaan, khususnya dalam kesadaran sejarah. Ia menjelaskan tiga persoalan dasar yang dijawabnya sendiri. ${ }^{18}$ Pertama, benarkah terdapat perbedaan horizon antara penafsir dengan horizon teks? Menurut Gadamer, memang ada perbedaan, tetapi tidak mungkin terjadi pemisahan antara penafsir dan teks. Sebaliknya yang terjadi adalah suatu keutuhan, horizon yang bergerak antara horizon penafsir dan teks.

Kedua, apakah seni memahami sejarah berdasarkan pada kemampuan menyibak sebuah horizon yang berbeda dari keyakinan seorang penafsir?. Dalam pandangan Gadamer, tidak mungkin jika seorang peneliti datang dari sebuah tabula rasa melainkan telah berpijak pada satu horizon tertentu. Ketiga, dapatkah seseorang berbicara secara umum tentang horizon yang tertutup? Gadamer memastikan bahwa

16 Hans-Georg Gadamer, Truth and Method..., hlm. 305.

17 F. Budi Hardiman, Seni Memahami..., hlm. 185.

18 Martinho G. Da Silva Gusmao, Hans-Georg Gadamer..., hlm.115-116. 
tidak ada horizon yang tertutup. Dalam konteks ini, dapat dipahami bahwa kerja dari fusion of horizon adalah mendialogkan horizon teks dan horizon penafsir sebagaimana dapat diketahui melalui bagan berikut.

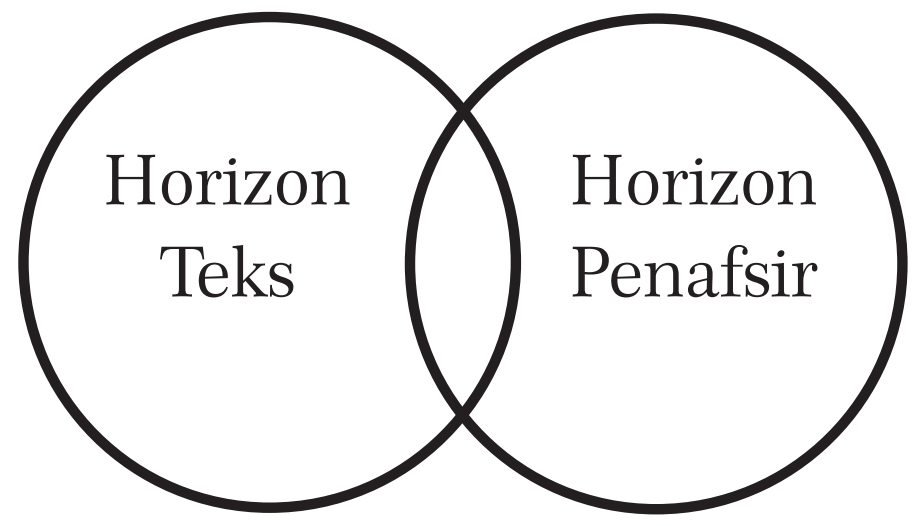

Kedua horizon tersebut berdiri dalam realitas sejarahnya masingmasing. Gadamer menyebut realitas sejarah tersebut dengan sebutan sejarah efektif atau effective history. Konsep ini dipahami untuk melihat tiga kerangka waktu yang mengitari teks historis. Pertama, masa lampau di mana teks tersebut dilahirkan dan makna teks bukan hanya milik pengarang, melainkan juga milik setiap orang yang membacanya. Kedua, masa kini di mana penafsir datang dengan 'segudang' prasangka (prejudice). Prasangka ini akan berdialog dengan masa sebelumnya sehingga menghasilkan suatu produksi makna. Ketiga, masa depan, di mana terdapat nuansa baru yang produktif. ${ }^{19}$

Lebih lanjut, menurut Gadamer, pemahaman akan lahir melalui dialektika antara masa lampau dan masa kini sehingga menghasilkan makna untuk masa depan. Lingkaran hermeneutis dan lingkaran waktu tersebut terus berputar sehingga makna yang dihasilkan pun akan terus berkembang. Kata kuncinya adalah bahwa horizon teks dan penafsir berada dalam suatu tradisi budaya dan sejarah yang terbentuk

19 Mohammad Muslih, Filsafat Ilmu: Kajian atas Asumsi Dasar Paradigma dan Kerangka Teori Ilmu Pengetahuan, (Yogyakarta: Belukar, 2005), hlm. 143. 
dalam kontinuitas (masa lalu, sekarang, dan masa depan) ${ }^{20}$ Karenanya cara kerja dari fusion of horizon adalah dengan memahami sejarah teks atau masa lampau dan mendialogkannya dengan sejarah saat ini sehingga yang terjadi adalah produksi makna baru. Fusion of horizon ini sebenarnya juga digunakan dalam penelitian-penelitian ilmiah yang menjadi contribution of knowledge.

Contoh peleburan horizon adalah penelitian yang dilakukan oleh Clifford Geertz. Dalam salah satu pembahasannya, ia sebagai seorang Amerika dan banyak belajar sastra Barat memahami struktur drama shakespeare untuk memahami struktur pertunjukan wayang Jawa. ${ }^{21}$ Hasil interpretasinya merupakan peleburan antara horizon Jawa dan horizon Geertz sebagai peneliti. Disinilah contribution of knowledge dari Geertz ketika mengkaji seputar tradisi Jawa.

Selanjutnya setelah memahami fusion of horizon, timbul permasalahan baru, bagaimana horizon teks dan penafsir dapat bertemu dan melebur? Apa mediumnya?. Menurut Palmer, mediumnya adalah bahasa. ${ }^{22}$ Ia juga menegaskan bahwa pengalaman hermeneutis adalah perjumpaan antara warisan budaya dalam bentuk sebuah transmisi teks dan horizon penafsir. Sedangkan pengalaman tidak hadir mendahului atau di luar bahasa, namun pengalaman itu sendiri terjadi di dalam dan melalui bahasa. ${ }^{23}$ Karenanya esensi (being) itu berekstensi melalui bahasa dan hanya bisa dipahami melalui bahasa. ${ }^{24}$

Selain itu, melalui bahasa yang dituangkan ke dalam teks, seorang penulis dapat menceritakan peristiwa masa lalu untuk dihadirkan kini dan di sini (now and here). Jarak ruang dan waktu dapat dipersempit dan diperluas oleh wawasan ilmu pengetahuan yang dikomunikasikan melalui bahasa. ${ }^{25}$ Sehingga semakin luas bahasa yang dimiliki oleh

20 Agus Darmaji, “Dasar-dasar Ontologis Pemahaman Hermeneutik Hans-Georg Gadamer”, Refleksi, Volume 13, Nomor 4, 2013, hlm. 481.

21 F. Budi Hardiman, Seni Memahami..., hlm. 184.

22 Richard E. Palmer, Hermeneutika Teori Baru..., hlm. 239.

23 Richard E. Palmer, Hermeneutika Teori Baru..., hlm. 246.

24 Mohammad Muslih, Filsafat Ilmu..., hlm. 142.

25 Komaruddin Hidayat, Memahami Bahasa Agama: Sebuah Kajian Hermeneutik, (Jakarta: 
seseorang, semakin besar pula cakupan horizon yang dapat diterima dan pada akhirnya melahirkan pemahaman yang lebih menyeluruh. Dalam konteks ini, menarik untuk melihat signifikansi penggunaan fusion of horizon dalam pengembangan kajian ulum Alquran. Apalagi tidak semua cendekiawan Muslim sepakat penggunaan hermeneutika dalam rangka memahami Alquran.

\section{Fusion of Horizons: Refleksi Kritis dalam Kajian Ulum Alquran}

Terkait dengan penggunaan fusion of horizons dalam memahami Alquran, ada yang pro dan kontra. Golongan yang pro misalnya Quraish Shihab, beliau menjelaskan:

Pandangan Gadamer menyangkut dialog imajinatif antara penafsir dan teks, adalah sesuatu yang baik, meskipun kedua pihak berebda waktu dan tempat. Ini pada dasarnya dapat diterima, bahkan diriwayatkan ungkapan yang dinisbahkan kepada Sayyidina Ali mengatakan istanthiq Alquran, ajaklah Alquran berbicara. Itulah antara lain yang diterapkan dalam metode maudhu'i. ${ }^{26}$

Selain itu, Abdullah Saeed sebagai penerus dari metode double movement Fazlur Rahman juga menggagas penafsiran kontekstual yang mempunyai semangat fusion of horizons. Dalam bukunya ia menjelaskan alasan menggunakan teori ini sebagai berikut:

"One reason why this project is important is that there is a strongly felt need among Muslims to make the Qur` anic teachings, in particular their ethico-legal content, relevant to the needs of Muslims today, as these have greatly changed from those of the past."27

Sejalan dengan Quraish Shihab dan Abdullah Saeed, Sahiron Syamsuddin juga mendukung penerapan teori tersebut dengan meneruskan teori dari Amin Al-Khuli yaitu dirasat ma fi al-nash

Paramadina, 1996), hlm. 37.

26 M. Quraish Shihab, Kaidah Tafsir: Syarat, Ketentuan dan Aturan yang Patut Anda Ketahui dalam Memahami Ayat-ayat Alquran, (Tangerang: Lentera Hati, 2013), hlm. 465.

27 Abdullah Saeed, Interpreting the Qur'an: Towards a Contemporary Approach, (London: Routledge, 2006), hlm. 5. 
dan dirasat ma hawla al-nash. Kedua konsep tersebut digunakan untuk mencari horizon teks. Sedangkan untuk membangun horizon penafsir dapat dilakukan dengan reaktualisasi penafsiran melalui interpretasi ma'na-cum-maghza. ${ }^{28}$ Tokoh lain yang juga terpengaruh dengan hermeneutika Gadamer adalah Hasan Hanafi dengan spirit hermeneutika pembebasannya. ${ }^{29}$

Di sisi lain, sejumlah tokoh mengkritik penggunaan fusion of horizons dalam memahami Alquran. Syamsuddin Arif menegaskan:

Hermeneutika menghendaki pelakunya untuk menganut relativisme epistemologis. Tidak ada tafsir yang mutlak benar, semuanya relatif. Yang benar menurut seseorang boleh jadi salah menurut orang lain. Kebenaran terikat dan bergantung pada konteks tertentu. Selain mengaburkan dan menolak kebenaran, faham ini juga akan melahirkan mufassir-mufassir gadungan dan pemikir-pemikir liar yang sesat lagi menyesatkan. ${ }^{30}$

Sejalan dengan Syamsuddin Arif, Fahmi Salim juga mengkritik penggunaan hermeneutika dalam penafsiran Alquran. Ia menjelaskan:

Para pengkaji dan pemerhati Islam di kalangan orientalis Barat yang gemar dengan studi-studi keislaman membawa misi penerapan "metode kritik Bibel" kepada bidang "studi Alquran" yang merupakan wahyu Tuhan dengan sebenarnya dan tidak pernah ada kebatilan baik sebelum maupun sesudahnya. Padahal mereka mengetahui bahwa Alquran bukanlah "produk" budaya karangan manusia, tetapi ia diturunkan Allah dari langit. Ia bukan produk budaya kemanusiaan yang bisa dimasuki unsur-unsur kekurangan seperti halnya kerja manusia. ${ }^{31}$

Menyikapi sikap pro dan kontra dari sejumlah akademisi, ada beberapa catatan kritis. Pertama, harus dibedakan antara Alquran dan tafsir. Kebenaran Alquran dalam konteks teologis Muslim adalah

28 Sahiron Syamsuddin, Hermeneutika..., hlm. 87.

29 Hasyim Hasanah, "Hermeneutik Ontologis-Dialektis Hans-Georg Gadamer (Produksi Makna Wayang sebagai Metode Dakwah Sunan Kalijogo)", At-Taqaddum, Volume 9, Nomor 1, 2017, hlm. 23.

30 Syamsuddin Arif, Orientalis \& Diabolisme Pemikiran, (Jakarta: Gema Insani, 2008), hlm. 183.

31 Fahmi Salim, Kritik terhadap Studi Alquran Kaum Liberal, (Jakarta: Perspektif, 2010), hlm. 183. 
absolut. Tetapi, penafsiran Alquran kebenarannya adalah relatif, tidak semua penafsiran dapat diterima. Bahkan antar ulama tafsir pun tidak jarang saling mengkritik satu sama lain. Karenanya yang 'tidak disakralkan' oleh para pemikir kontemporer adalah aspek pemahaman dan penafsiran manusia terhadap Alquran..$^{32}$ Dalam hal ini, sebagaimana pendapat Fahmi Salim di atas, bahwa pemahaman manusia terdapat celah kesalahan dan keluputan, termasuk di dalamnya tafsir yang merupakan produk pemikiran manusia.

Kedua, fusion of horizon merupakan bagian dari hermeneutika filosofis yang digagas Gadamer. Sebagaimana pembahasan sebelumnya, hermeneutika filosofis justru berbeda dengan hermeneutika metodologis. Sehingga kurang tepat juga jika men-generalisir semua hermeneutika untuk kajian Bibel. Memang dalam sejarahnya tidak dipungkiri, tetapi, dalam perkembangannya hermeneutika filosofis Gadamer dapat digunakan untuk semua teks.

Ketiga, fusion of horizon yang ditawarkan oleh Gadamer justru dapat menjadi tolok ukur memahami tafsir yang benar dan keliru. Poinnya adalah seberapa besar dialektika atau peleburan antara horizon teks dan horizon pembaca. Dalam konteks ini, fusion of horizon dapat menjadi kritik bagi tafsir yang cenderung mengedepankan makna literal teks kebahasaan ataupun tafsir yang cenderung liberal sesuai dengan pemahaman penafsir tanpa menggunakan dasar-dasar ulum Alquran.

Keempat, fusion of horizon tidak mengganggu sakralitas Alquran. setiap Muslim dapat membawa dimensi sakralitas, pengagungan Alquran dalam memahami ayat-ayat Alquran. Dalam konteks ini, pra pemahaman seorang mufassir berangkat dari semangat bahwa Alquran merupakan wahyu Tuhan.

Kelima, horizon teks Alquran dapat diketahui tidak dengan meneliti pengarangnya yaitu Allah. Tetapi, horizon teks dibangun dengan memahami bahasa teks dan sejarah yang melingkupinya.

32 Fahruddin Faiz, Hermeneutika Alquran: Tema-tema Kontroversial, (Yogyakarta: Kalimedia, 2015), hlm. 41. 
Penting juga untuk melacak pemahaman awal generasi sahabat dalam memahami Alquran sebagai saksi sekaligus pelaku sejarah teks Alquran.

Keenam, fusion of horizon dapat mendorong para mufassir atau pembaca Alquran untuk memperluas cakrawalanya sehingga dapat melebur dengan horizon teks. Setidaknya beberapa kitab-kitab ulum Alquran seperti al-Itqan fi 'Ulum Alquran telah membahas hal tersebut. ${ }^{33}$ Contoh yang paling sederhana adalah mengetahui bahasa Arab. Sebab, seseorang tidak akan dapat memahami horizon teks Alquran tanpa memahami bahasa Arab. Oleh karena itu, pengembangan tafsir maqasid Alquran menjadi salah satu alternatif yang sejalan dengan spirit fusion of horizon.

\section{E. Fusion of Horizon dalam Pengembangan Tafsir Maqasid Alquran}

Sebagaimana pembahasan sebelumnya, Quraish Shihab menyebutkan bahwa fusion of horizons Gadamer selaras dengan metode tafsir tematik (maudhu'i). ${ }^{34}$ Dalam konteks tersebut, Jasser Auda menuturkan penafsiran maqasid Alquran erat kaitannya dengan kajian tafsir tematik (thematic exegesis school) yang lebih mempertimbangkan aspek maqasid. Melalui pembacaan tersebut, maka diharapkan Alquran dapat menjadi kesatuan yang menyeluruh (unified whole). ${ }^{35}$ Aspek maqasid yang dimaksud merupakan spirit atau titik temu antara horizon teks di masa silam dan horizon penafsir saat ini.

33 Imam al-Suyuthi memberikan penjelasan mengenai hal-hal apa saja yang perlu dipersiapkan dan diketahui oleh seorang mufassir. Beliau membahas dalam beberapa bab, yaitu fi ma'rifah ma'ani al-adawat allati yuhtaju ilaiha al-mufasssir; fi qawa'id muhimmah yuhtaj al-mufassir ila ma'rifatiha; dan fi ma'rifah syuruth al-mufassir wa adabih; lebih lanjut lihat Jalal al-Din al-Suyuthi, al-Itqan fi 'Ulum Alquran, (Beirut: Risalah Publisher, 2008).

34 M. Quraish Shihab, Kaidah Tafsir..., hlm. 465.

35 Jasser Auda, Maqāşid al-Shariah as Philosophy of Islamic Law: A Systems Approach, (London: The International Institute of Islamic Thought, 2007), hlm. 232. 


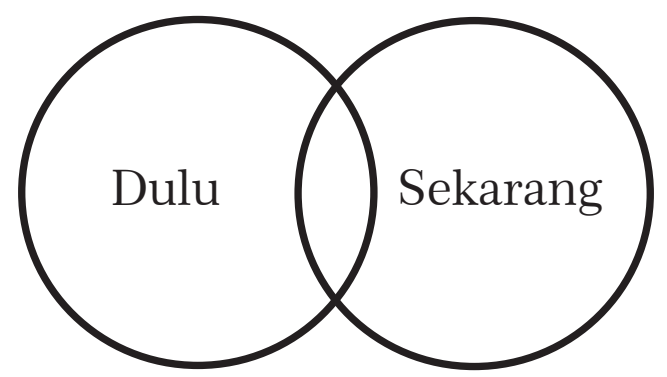

Garis tengah yang mengubungkan antara dahulu dan saat ini, itulah maqasid atau substansi dari ayat Alquran. Menggali dan memahami maqasid Alquran inilah yang menjadi tugas seorang mufasir. Dalam bahasa lain, seorang mufasir seharusnya dapat mendialogkan antara teks dan realitas yang dihadapi oleh masyarakat modern saat ini. Karenanya tafsir maqasid sejalan dengan fusion of horizons yang ditawarkan oleh Gadamer. Adapun beberapa langkah yang dapat dilakukan untuk memahami maqasid Alquran sebagai berikut.

Pertama, memahami horizon teks, setidaknya ada dua hal utama yang harus ditekankan dalam memahami horizon teks, yaitu memahami konteks sejarah Alquran dan memahami penggunaan bahasa Arab yang digunakan saat Alquran turun. ${ }^{36}$ Membangun horizon teks semacam ini sebenarnya sudah dilakukan oleh ulamaulama Alquran tradisional seperti al-Suyuthi.

Membangun kesadaran sejarah Alquran misalnya dilakukan dengan mengkaji al-makki dan al-madani, al-hadhari al-safari, alnahari dan al-laili, al-shaifi dan al-syita 'i, al-firasyi dan al-naumi, alardhi dan al-sama'i, dan al-asbab al-nuzul. ${ }^{37}$ Sedangkan membangun kematangan bahasa Alquran dapat dilakukan melalui analisis i'rab Alquran, al-muhkam dan al-mutasyabih, 'am dan khash, mujmal dan mubayyan, muthlaq dan muqayyad, manthuq dan mafhum, haqiqah

36 Dalam konteks ini, horizon teks yang dibangun oleh Gadamer memiliki semangat yang sama dengan hermeneutika grammatikal Schleiermacher, lebih lanjut lihat Sahiron Syamsuddin, Hermeneutika..., hlm. 66-68; dan F. Budi Hardiman, Seni Memahami..., hlm. 35-39.

37 Jika merujuk pada pembahasan ulama modern, asbab al-nuzul dapat dikatakan sebagai konteks sejarah mikro, sedangkan selain itu merupakan cara untuk memahami konteks sejarah makro. Lebih lanjut lihat Jalal al-Din al-Suyuthi, al-Itqan fi 'Ulum Alquran.... 
dan majaz, tasybih dan istiarah, amtsal Alquran, aqsam Alquran, ${ }^{38}$ dan lain-lain.

Hanya saja, catatan kritis dari metodologi yang dikembangkan oleh ulama klasik tersebut adalah kurangnya menangkap pesan maqasid dan didialogkan dengan kondisi kekinian. Sehingga salah satu solusinya adalah mengembangkan ulum Alquran dengan pembacaan ilmu-ilmu modern seperti sosiologi, antropologi, hermeneutika, dan lain-lain. ${ }^{39}$

Kedua, setelah memahami horizon teks, mufasir harus menggali maqasid dari teks tersebut. Jaser Auda ${ }^{40}$ menawarkan beberapa langkah untuk menangkap maqasid Alquran sebagai berikut:

a. Membedakan antara makna yang berubah dan makna yang tetap

Pemahaman semacam itu telah digaungkan oleh beberapa ulama sebelumnya di antaranya Muhammad al-Ghazali yang membedakan antara al-wasa'il (sarana) dan al-ahdaf (tujuan), Yusuf al-Qaradhawi dalam memahami hadis harus membedakan antara sarana yang berubah-ubah ${ }^{41}$ dan tujuan yang tetap. ${ }^{42}$

b. Pemahaman yang menyeluruh dengan menelaah ayat-ayat yang bertentangan

Sejumlah ulama menawarkan beberapa metode dalam menghadapi pertentangan antar dalil misalnya metode aljam'u, nasakh, al-tarjih, al-tawaqquf, al-tasaqut, dan al-takhyir. ${ }^{43}$

38 Lebih lanjut lihat Jalal al-Din al-Suyuthi, al-Itqan fi 'Ulum Alquran....

39 Salah satu kajian integrasi antara ulum Alquran klasik dan ilmu modern adalah penelitian seputar pengembangan asbab al-nuzul dalam konteks historis-sosiologis. Lebih lanjut lihat Abad Badruzaman, Dialektika Langit dan Bumi, (Bandung: Mizan, 2018).

40 Lebih lanjut lihat Rahmatullah, "Kebebasan Beragama dalam Alquran Perspektif Maqasid al-Syariah Jasser Auda", Skripsi Fakultas Ushuluddin dan Pemikiran Islam UIN Sunan Kalijaga, Yogyakarta, 2017, hlm. 70-76.

$41 \mathrm{Al}-\mathrm{Q} a r a d h a w i$ memahami ada beberapa faktor perubah fatwa, di antaranya faktor tempat, waktu, kondisi, tradisi ('urf), ilmu pengetahuan, kebutuhan manusia, kemampuan manusia, kondisi sosial, ekonomi,dan politik, pendapat dan pemikiran, dan faktor musibah. Lebih lanjut lihat Yusuf Al-Qaradhawi, Faktor-faktor Pengubah Fatwa, terj. Arif Munandar Riswanto, (Jakarta: Al-Kautsar, 2009).

42 Suryadi, Metode Kontemporer Memahami Hadis Nabi: Perspektif Muhammad al-Ghazali dan Yusuf al-Qaradhawi, (Yogyakarta: Teras, 2008), hlm. 168.

43 Jasser Auda, Membumikan Hukum Islam melalui Maqasid Syariah, terj. Rosidin dan Ali Abd el-Mun'im, (Bandung: Mizan, 2015), hlm. 286. 
Menyoroti metode-metode tersebut, Jasser Auda menegaskan bahwa metode konsiliasi (al-jam'u) menjadi solusi dan terobosan dalam rangka memfungsikan konsep multi-dimensionalitas dan menangkap maqasid Alquran secara menyeluruh. ${ }^{44}$

Oleh karena itu, dalam rangka menggali dan memahami maqasid dari ayat-ayat Alquran, maka metode yang tepat untuk diaplikasikan adalah dengan menggabungkan dan melihat maqasid dari setiap ayat, kemudian menghubungkannya satu dengan yang lain sehingga tercipta satu konsep yang utuh dan menyeluruh.

c. Nilai-nilai universal syariat

Dalam rangka memahami nilai universal tersebut dengan menggunakan maqasid Alquran, ada beberapa langkah yang dapat dilakukan sebagai berikut: ${ }^{45}$

1. Mengekstrak "konsep-konsep" yang membentuk fenomena yang hendak dikaji.

2. Langkah kedua adalah mencari "ushul" atau teori-teori yang memerintahkan.

3. Langkah ketiga perlu diterangkan hubungan antara konsepkonsep dan teori-teori tersebut, sehingga mulai terkumpul jejaring relasi antar konsep-konsep itu.

4. Langkah keempat perlu ditarik apa yang disebut 'sunnatullah" dalam setiap tema atau isu yang hendak dicari solusinya dalam menafsirkan Alquran secara kontemporer.

5. Langkah kelima adalah menemukan "nilai-nilai" atau aturanaturan akhlak yang memerintahkan ahkam detail dari Islam.

Berdasarkan langkah-langkah yang ditawarkan oleh Jasser Auda tersebut, sebenarnya proses penarikan nilai-nilai universal (maqasid) mulai menggabungkan antara horizon teks dan pembaca. Setelah

44 Jasser Auda, Membumikan Hukum Islam..., hlm. 287.

45 Kuliah Umum disampaikan oleh Jasser Auda, di Teatrikal Fakultas Ushuluddin UIN Sunan Kalijaga Yogyakarta tanggal 13 Maret 2017. 
memperoleh satu maqasid al-'ammah (maksud umum) dari satu pembahasan tematik, kemudian dilanjutkan dengan proses peleburan (fusion) antara teks dan realitas.

Ketiga, mendialogkan maqasid Alquran dengan horizon kekinian. Setelah memahami maqasid Alquran, lantas penafsir dapat memberikan penjelasan bagaimana melaksanakan perintah Alquran tersebut dalam konteks kehidupan saat ini. Tahapan ini dalam bahasa Gadamer disebut dengan aplikasi (subtilitas applicandi). Maksudnya adalah bahwa aplikasi merupakan bagian integral dari pemahaman. Seorang penafsir memahami dengan mengaplikasikan teks, termasuk teks Alquran. Hal ini terjadi karena pemahaman merupakan hasil peleburan horizon-horizon. ${ }^{46}$

Salah satu contoh yang familiar adalah memahami ayat 'potong tangan' bagi pencuri. Setelah melalui analisis kebahasaan dan historis yang panjang, dapat ditarik satu benang merah bahwa maqasid dari hukum tersebut adalah untuk menimbulkan efek jera. Maka penafsir dapat mengaplikasikan ayat tersebut tidak dengan menggunakan hukum potong tangannya, tetapi menarik spirit efek jeranya. Lantas, menyimpulkan bahwa hukuman bagi pencuri adalah dengan dimasukkan ke dalam penjara. Pemahaman semacam ini adalah bagian dari semangat fusion of horizons.

\section{F. Penutup}

Hermeneutika Gadamer menjadi salah satu tawaran alternatif untuk memahami teks secara proporsional. Salah satu gagasannya yaitu fusion of horizon dapat diaplikasikan untuk memahami setiap teks termasuk teks kitab suci. Karenanya, pemahaman adalah suatu tindakan aktif dan terus bergerak tidak pernah final sesuai dengan horizon yang mengitarinya.

Sikap terbaik untuk mendapatkan pemahaman yang komprehensif adalah pertama, kemauan terbuka untuk menerima gagasan dan

46 F. Budi Hardiman, Seni Memahami..., hlm. 189. 
wawasan baru. Hal ini penting untuk memperluas cakrawala seseorang sehingga ia dapat menjangkau hal-hal yang lebih luas lagi. Kedua, menghasilkan pemahaman baru atau memproduksi sesuatu yang baru. Meski demikian, perlu digarisbawahi bahwa kebaruan gagasan tidak dapat diperoleh tanpa memahami sejarah masa lampau.

Ketiga, pemahaman yang efektif bukanlah pemahaman yang berdiri sendiri, justru pemahaman yang valid adalah pemahaman yang bersumber dan ditopang dari horizon-horizon yang beragam. Semakin luas horizon, semakin luas pula pemahamannya. Keempat, semangat fusion of horizon dapat dikembangkan dalam konteks memahami Alquran dengan menggunakan tafsir maqasid Alquran, sehingga nilai-nilai Alquran dapat selaras dengan waktu dan tempat, shalih li kulli zaman wa makan.

Oleh karena itu, fusion of horizon mendorong para peneliti untuk terus memperluas wawasan, tidak berhenti dalam satu pemahaman yang stagnan. The last but not least, seseorang yang memiliki cakrawala pengetahuan luas akan terbuka dan lebih dewasa dalam menyikapi perbedaan, termasuk perbedaan dalam memahami teks-teks keagamaan. Wallahu a lam bish showwab.

\section{DAFTAR PUSTAKA}

Arif, Syamsuddin. Orientalis \& Diabolisme Pemikiran. Jakarta: Gema Insani, 2008.

Auda, Jasser. Maqasid al-Shariah as Philosophy of Islamic Law: A Systems Approach. London: The International Institute of Islamic Thought, 2007.

. Membumikan Hukum Islam melalui Maqasid Syariah. terj. Rosidin dan Ali Abd el-Mun’im. Bandung: Mizan, 2015.

Badruzaman, Abad. Dialektika Langit dan Bumi. Bandung: Mizan, 2018. Darmaji, Agus. "Dasar-dasar Ontologis Pemahaman Hermeneutik Hans Georg Gadamer”. Refleksi. Volume 13, Nomor 4, 2013. 
Faiz, Fahruddin. Hermeneutika Alquran: Tema-tema Kontroversial. Yogyakarta: Kalimedia, 2015.

Gadamer, Hans-Georg. Truth and Method. Terj. Joel Weinsheimer dan Donald G. Marshall. London: Continuum, 2004. . Philosophical Hermeneutics. Terj. David E. Linge. London: University of California Press, 2008.

Gusmao, Martinho G. Da Silva. Hans-Georg Gadamer: Penggagas Filsafat Hermeneutik Modern yang Mengagungkan Tradisi. Yogyakarta: Kanisius, 2012.

Hardiman, F. Budi. Seni Memahami: Hermeneutik dari Schleiermacher sampai Derrida. Yogyakarta: Kanisius, 2015.

. Melampaui Positivisme dan Modernitas: Diskursus Filosofis tentang Metode Ilmiah dan Problem Modernitas. Yogyakarta: Kanisius, 2003.

Hasanah, Hasyim. "Hermeneutik Ontologis-Dialektis Hans-Georg Gadamer”. At-Taqaddum. Volume 9, Nomor 1, 2017.

Hidayat, Komaruddin. Memahami Bahasa Agama: Sebuah Kajian Hermeneutik. Jakarta: Paramadina, 1996.

Kuliah Umum disampaikan oleh Jasser Auda, di Teatrikal Fakultas Ushuluddin UIN Sunan Kalijaga Yogyakarta tanggal 13 Maret 2017.

Muslih, Mohammad. Filsafat Ilmu: Kajian atas Asumsi Dasar Paradigma dan Kerangka Teori Ilmu Pengetahuan. Yogyakarta: Belukar, 2005.

Palmer, Richard E. Hermeneutika Teori Baru Mengenai Interpretasi. Terj. Musnur Hery dan Damanhuri Muhammed. Yogyakarta: Pustaka Pelajar, 2005.

Al-Qaradhawi, Yusuf. Faktor-faktor Pengubah Fatwa. terj. Arif Munandar Riswanto. Jakarta: Al-Kautsar, 2009.

Rahmatullah, "Kebebasan Beragama dalam Alquran Perspektif Maqasid al-Syariah Jasser Auda", Skripsi Fakultas Ushuluddin dan 
Pemikiran Islam UIN Sunan Kalijaga, Yogyakarta, 2017.

Saeed, Abdullah. Interpreting the Qur'an: Towards a Contemporary Approach. London: Routledge, 2006.

Salim, Fahmi. Kritik terhadap Studi Alquran Kaum Liberal. Jakarta: Perspektif, 2010.

Shihab, M. Quraish. Kaidah Tafsir: Syarat, Ketentuan dan Aturan yang Patut Anda Ketahui dalam Memahami Ayat-ayat Alquran. Tangerang: Lentera Hati, 2013.

Sumaryono, E. Hermeneutik Sebuah Metode Filsafat: Edisi Revisi. Yogyakarta: Kanisius, 1999.

Suryadi. Metode Kontemporer Memahami Hadis Nabi: Perspektif Muhammad al-Ghazali dan Yusuf al-Qaradhawi. Yogyakarta: Teras, 2008.

Al-Suyuthi, Jalal al-Din. Al-Itqan fi 'Ulum Alquran. Beirut: Risalah Publisher, 2008.

Syamsuddin, Sahiron. Hermeneutika dan Pengembangan Ulumul Qur 'an: Edisi Revisi dan Perluasan. Yogyakarta: Nawasea Press, 2017. 